\title{
How CER could pay for itself - insights from vertebral fracture treatments
}

\section{Citation}

Elshaug, Adam G., and Alan M. Garber. 2011. How CER could pay for itself - insights from vertebral fracture treatments. New England Journal of Medicine 364, no. 15:1390-1393.

\section{Published Version}

doi:10.1056/NEJMp1101475;http://www.nejm.org/doi/full/10.1056/NEJMp1101475

\section{Permanent link}

http://nrs.harvard.edu/urn-3:HUL.InstRepos:11595669

\section{Terms of Use}

This article was downloaded from Harvard University's DASH repository, and is made available under the terms and conditions applicable to Other Posted Material, as set forth at http:// nrs.harvard.edu/urn-3:HUL.InstRepos:dash.current.terms-of-use\#LAA

\section{Share Your Story}

The Harvard community has made this article openly available.

Please share how this access benefits you. Submit a story.

\section{Accessibility}


implemented. The FDA is committed to pursuing these answers with the medical and scientific communities and will take the steps necessary to ensure that the benefits of anesthetic use in children continue to outweigh any potential risks.

Disclosure forms provided by the authors are available with the full text of this article at NEJM.org.

From the Division of Anesthesia and Analgesia Products, Office of New Drugs (B.R.
R.D.M., A.S.) and the Center for Drug Evaluation and Research (J.W.), Food and Drug Administration, Silver Spring, MD.

This article (10.1056/NEJMpl102155) was published on March 9, 2011, at NEJM.org.

1. Slikker W Jr, Zou X, Hotchkiss CE, et al. Ketamine-induced neuronal cell death in the perinatal rhesus monkey. Toxicol Sci 2007; 98:145-58

2. Brambrink AM, Evers AS, Avidan MS, et al. Isoflurane-induced neuroapoptosis in the neonatal rhesus macaque brain. Anesthesiology 2010;112:834-41.

3. Paule MG, Li M, Allen RR, et al. Ketamine anesthesia during the first week of life can cause long-lasting cognitive deficits in rhesus monkeys. Neurotoxicol Teratol 2011 January 15 (Epub ahead of print).

4. DiMaggio C, Sun LS, Kakavouli A, Byrne MW, Li G. A retrospective cohort study of the association of anesthesia and hernia repair surgery with behavioral and developmental disorders in young children.J Neurosurg Anesthesiol 2009;21:286-91.

5. Wilder RT, Flick RP, Sprung J, et al. Early exposure to anesthesia and learning disabilities in a population-based birth cohort. Anesthesiology 2009;110:796-804.

Copyright @ 2011 Massachusetts Medical Society.

\section{How CER Could Pay for Itself — Insights from Vertebral Fracture Treatments}

Adam G. Elshaug, M.P.H., Ph.D., and Alan M. Garber, M.D., Ph.D.

r he pain and disability caused by osteoporotic vertebral fractures have long motivated the search for effective therapy. Two procedures designed to restore vertebral body height and function have been widely adopted: percutaneous vertebroplasty, in which cement is injected into the vertebral body to support the fractured bone; and kyphoplasty, a variant of vertebroplasty in which a balloon is inserted and inflated in a collapsed vertebral body, restoring the bone's height before the cement injection. Initial studies suggested that these procedures were superior to conventional symptomatic treatment. But when later studies cast doubt on those favorable findings, health care funding agencies sought to curb their use. The story of these procedures offers a glimpse of the ways in which comparative-effectiveness research (CER) may influence medical practice and health care expenditures.

Early studies of these procedures were neither randomized nor blinded, and because the symptoms of compression fractures often abated over time, the lack of adequate controls made it impossible to know whether improvements that followed treatment would have occurred even without surgery. Furthermore, neither procedure was risk-free; reported complications included compression fractures, cement leakage, pulmonary complications, paraplegia, and death. ${ }^{1}$ In a scenario that's likely to be repeated frequently as CER gains greater acceptance and support, randomized trials eventually followed the observational studies that had fostered the initial enthusiasm. $^{2}$ If the full consequences of that research are not yet fully apparent, their potential importance is. Were the results of better-designed studies translated into practice, the reduction in U.S. health care expenditures would be considerable.

CER treats effectiveness as a balance of benefits and harms; when the risks associated with a procedure outweigh its clinical benefits, it is appropriate and ethical to limit its use. Both the clinical need and the desire to avoid wasteful expenditures were part of the rationale for subjecting these procedures to comparative studies. Furthermore, consensus that these procedures were promising but unproven led several countries to make them available on an interim-coverage basis. These arrangements, in effect from 2006 through 2010, allowed the procedures to be performed in everyday practice while further evidence was generated.

Trials conducted during that period suggested that kyphoplasty did not improve outcomes. The studies of vertebroplasty produced varying results, but the highestquality trials cast doubt on the benefit and raised additional safety concerns. In a randomized but non-blinded trial by Kallmes et al., ${ }^{3}$ patients who underwent vertebroplasty and controls had similar reductions in disability and pain scores, with a trend toward a higher rate of clinically meaningful improvement in pain 
Vertebroplasty and Kyphoplasty Volumes and Costs in the United States, with Potential Savings from Decreased Use*

\begin{tabular}{|c|c|c|c|c|c|c|}
\hline Payer (Data Source) & Procedure & $\begin{array}{c}\text { Total Estimated } \\
\text { No. of Procedures } \\
\text { (\% Accounted } \\
\text { for by Specified } \\
\text { Payer) }\end{array}$ & $\begin{array}{c}\text { Mean } \\
\text { Cost per } \\
\text { Procedure }\end{array}$ & $\begin{array}{l}\text { Aggregate } \\
\text { Costs } \\
\text { in } 2008\end{array}$ & $\begin{array}{l}\text { Annual } \\
\text { Savings } \\
\text { with a 50\% } \\
\text { Decrease in } \\
\text { Utilization } \\
\text { dollars }\end{array}$ & $\begin{array}{c}\text { Annual } \\
\text { Savings } \\
\text { with an } 80 \% \\
\text { Decrease in } \\
\text { Utilization }\end{array}$ \\
\hline \multirow[t]{2}{*}{ Medicare (NIS) } & Vertebroplasty & $11,253(82.2)$ & 11,411 & $128,407,983$ & $64,203,992$ & $102,726,386$ \\
\hline & Kyphoplasty & $19,397(82.7)$ & 14,336 & $278,075,392$ & $139,037,696$ & $222,460,314$ \\
\hline \multirow[t]{2}{*}{ Medicare (SASD) } & Vertebroplasty & $6,260(77.7)$ & 4,451 & $27,863,260$ & $13,931,630$ & $22,290,608$ \\
\hline & Kyphoplasty & $11,684(76.2)$ & 7,328 & $85,620,352$ & $42,810,176$ & $68,496,282$ \\
\hline \multirow[t]{2}{*}{ Medicare total (NIS + SASD) } & Vertebroplasty & $17,513(80.5)$ & - & $156,271,243$ & $78,135,622$ & $125,016,994$ \\
\hline & Kyphoplasty & $31,081(80.1)$ & - & $363,695,744$ & $181,847,872$ & $290,956,595$ \\
\hline \multirow[t]{2}{*}{ Private insurance (NIS) } & Vertebroplasty & $1,522(11.1)$ & 14,514 & $22,090,308$ & $11,045,154$ & $17,672,246$ \\
\hline & Kyphoplasty & $2,992(12.8)$ & 11,968 & $35,808,256$ & $17,904,128$ & $28,646,604$ \\
\hline \multirow[t]{2}{*}{ Private insurance (SASD) } & Vertebroplasty & $1,341(16.6)$ & 4,865 & $6,523,965$ & $3,261,983$ & $5,219,172$ \\
\hline & Kyphoplasty & $2,913(18.9)$ & 9,945 & $28,969,785$ & $14,484,893$ & $23,175,828$ \\
\hline \multirow[t]{2}{*}{ Private insurance total (NIS + SASD) } & Vertebroplasty & $2,863(13.2)$ & - & $28,614,273$ & $14,307,137$ & $22,891,418$ \\
\hline & Kyphoplasty & $5,905(15.2)$ & - & $64,778,041$ & $32,389,021$ & $51,822,433$ \\
\hline $\begin{array}{l}\text { Combined total of principal } \\
\text { procedures }\end{array}$ & - & $57,362(94.8)$ & - & $613,359,301$ & $306,679,652$ & $490,687,440$ \\
\hline \multirow[t]{2}{*}{ Medicare, secondary procedure (NIS) } & Vertebroplasty & 3,024 & 11,411 & $34,506,864$ & $17,253,432$ & $27,605,491$ \\
\hline & Kyphoplasty & 14,932 & 14,336 & $214,065,152$ & $107,032,576$ & $171,252,122$ \\
\hline \multirow{2}{*}{$\begin{array}{l}\text { Private insurance, secondary } \\
\text { procedure (NIS) }\end{array}$} & Vertebroplasty & 653 & 14,514 & $9,477,642$ & $4,738,821$ & $7,582,114$ \\
\hline & Kyphoplasty & 2,979 & 11,968 & $35,652,672$ & $17,826,336$ & $28,522,138$ \\
\hline Grand Total, Principal + Secondary & - & 78,950 & - & $907,061,631$ & $453,530,817$ & $725,649,305$ \\
\hline
\end{tabular}

* Data are from the 2008 Nationwide Inpatient Sample (NIS) and the State Ambulatory Surgery Databases (SASD) of the Healthcare Cost and Utilization Project, Agency for Healthcare Research and Quality (AHRQ). ${ }^{5}$ Complete SASD data were analyzed and provided by Claudia Steiner of AHRQ. Primary procedures not paid for by Medicare or private insurance were provided to patients with Medicaid or no insurance. The estimates of budget impact are conservative, in part because we used costs (as reported to the Centers for Medicare and Medicaid Services) instead of charges or actual payments, and in part because the SASD covers only 28 states. We conservatively estimate that $17,000(80 \%)$ of the NIS procedures coded as secondary were actually the major procedure performed; SASD coded fewer than 3000 procedures as secondary, and these have been excluded from the analysis.

(30\% decrease from baseline) in the vertebroplasty group that neared statistical significance (64\% vs. $48 \%, \mathrm{P}=0.06)$. In a randomized, blinded trial by Buchbinder et al., ${ }^{4}$ vertebroplasty did not have a statistically significant advantage over placebo in any measured outcome over 6 months, although pain diminished in both groups.

These studies illustrate the difficulty of inferring the effects of treatments for a condition with a variable time course, particularly when its manifestations are strongly influenced by placebo effects. But the studies at best cast doubt on the magnitude of any benefits from these procedures and at worst established their ineffectiveness. The findings led U.S. and other payers to revisit their interim funding decisions. To improve safety and quality and to respond to pres- sures for fiscal responsibility and efficiency in health care, payers are deciding to limit or withdraw coverage for these procedures. In late 2010, the Blue Cross Blue Shield Association's Medical Advisory Panel confirmed its decision that neither procedure met its criteria for established effectiveness, and in Canada, the Ontario Health Technology Advisory Committee ruled that vertebroplasty should not be considered 
the standard treatment for osteoporotic vertebral fractures.

Any CER agenda strives for improved safety and quality of care. By identifying relative ineffectiveness, CER may also improve the health care system by freeing up resources to be used for safer and more effective forms of care. Savings from limiting the use of care whose effectiveness is unproven can be substantial,
Centered Outcomes Research Institute, created by the Affordable Care Act (ACA), is fully operational, its budget is expected to reach $\$ 500$ million annually, or just two thirds of the potential savings each year from diminished use of just two apparently ineffective procedures.

The savings might be reduced if patients who don't receive one of these procedures end up being

Without randomized trials, ineffective and costly treatments with risks and complications would continue to be

\section{administered largely because the alternative treatments are disappointing.}

whether the intervention is new or has already been disseminated. According to our analyses of data from the Healthcare Cost and Utilization Project, 5 in 2008 the cost of kyphoplasty and vertebroplasty was approximately $\$ 1$ billion. The table shows the estimated savings in the United States, by insurance type, under alternative assumptions about reductions in utilization. A 50\% reduction in utilization would deliver annual savings of $\$ 450$ million; an $80 \%$ reduction would save about $\$ 725$ million annually. Since these figures are based on costs rather than charges or payments, they are highly conservative. And although these figures appear small relative to U.S. health care expenditures, the procedures are not among the most common. Furthermore, savings are large in relation to the $\$ 1.1$ billion that Congress allocated to CER in the 2009 American Recovery and Reinvestment Act. When the Patient- treated more aggressively with other forms of care. For example, patients who do not undergo vertebroplasty might receive more pain medications or physical therapy than patients who undergo the procedure. However, such offsets in savings would be substantial only if the procedures greatly diminish symptoms for an extended period. Furthermore, the cost-savings estimates don't take into account expenditures for the treatment of adverse effects of the procedures.

CER won't always yield definitive conclusions about a therapy's effectiveness; individual patients might benefit despite disappointing results in randomized trials. But the adoption of a procedure in routine practice, if not part of a well-designed study, probably won't reveal the characteristics of the patients likely to benefit. If observational studies are well designed and build on clinically detailed data, they can often eluci- date information about subgroups that were not studied in a trial. But the limitations of conventional observational studies for a condition with fluctuating symptoms and whose main manifestation is pain apply here: without double blinding and closely matched controls, it will be surpassingly difficult to distinguish the effects of the intervention from the natural history of the condition. Thus, without randomized trials, ineffective and costly treatments with risks and complications would continue to be administered largely because the alternative treatments are disappointing. If nothing else, well-designed studies demonstrating ineffectiveness can help redirect research toward the development of alternatives.

Of course, savings will be derived from CER only if practice changes. In the United States, it's unclear whether these studies are powerful enough to overturn coverage decisions or cut utilization of established procedures. The status quo plays a large role in determining the burden of proof for interventions: if a procedure has spread widely, large, well-designed studies must show that it's clearly ineffective or harmful before payers and providers will abandon it; for a new procedure, the assumption is that effectiveness has not been established, so good studies demonstrating effectiveness are required for its adoption. Increasingly, funding agencies and policymakers aim to subject established practices to greater scrutiny, since often interventions adopted without strong evidence are later found to be ineffective or not as effective as initially thought.

ACA features such as bundled 
payments, shared savings programs, and outcomes-based payments offer mechanisms for stimulating the adoption of practices that are supported by CER and the abandonment of practices that CER calls into question. The benefits for patients are large, as are the potential savings. Support for CER, reinforced by appropriate payment changes, is likely to represent a very good investment for the federal government and U.S. taxpayers.

The views expressed in this article are those of the authors and do not necessarily represent those of the Commonwealth Fund or its directors, officers, or staff, or those of the Department of Veterans Affairs or Stanford University.

Disclosure forms provided by the authors are available with the full text of this article at NEJM.org.

From the International Program in Health Policy and Practice, Commonwealth Fund, New York (A.G.E.); the School of Population Health and Clinical Practice, University of Adelaide, Adelaide, SA, Australia (A.G.E.); the Veterans Affairs Palo Alto Health Care System, Palo Alto, CA (A.M.G.); and the Center for Health Policy and Center for Primary Care and Outcomes Research, Stanford University, Stanford, CA (A.M.G.).

1. Manufacturer and User Facility Device Experience Database (MAUDE). Silver
Spring, MD: Food and Drug Administration. (http://www.fda.gov/MedicalDevices/ DeviceRegulationandGuidance/Postmarket Requirements/ReportingAdverseEvents/ ucml27891.htm.)

2. Weinstein JN. Balancing science and informed choice in decisions about vertebroplasty. N EnglJ Med 2009;361:619-21.

3. Kallmes DF, Comstock BA, Heagerty PJ, et al. A randomized trial of vertebroplasty for osteoporotic spinal fractures. N Engl J Med 2009;361:569-79.

4. Buchbinder R, Osborne RH, Ebeling PR, et al. A randomized trial of vertebroplasty for painful osteoporotic vertebral fractures. N Engl J Med 2009;361:557-68.

5. Healthcare Cost and Utilization Project home page. Rockville, MD: Agency for Healthcare Research and Quality. (http:// hcupnet.ahrq.gov.)

Copyright (๔) 2011 Massachusetts Medical Society. 